\begin{tabular}{|l|l|l||}
\hline \multicolumn{2}{|c|}{ PublisherInfo } \\
\hline \hline PublisherName & $:$ & BioMed Central \\
\hline \hline PublisherLocation & $:$ & London \\
\hline \hline PublisherImprintName & $:$ & BioMed Central \\
\hline \hline
\end{tabular}

\title{
Little fire ant males are clones
}

\begin{tabular}{|l|l|l||}
\hline \multicolumn{2}{|c|}{ ArticleInfo } \\
\hline \hline ArticleID & $:$ & 5099 \\
\hline \hline ArticleDOI & $:$ & $10.1186 /$ gb-spotlight-20050630-01 \\
\hline \hline ArticleCitationID & $:$ & spotlight-20050630-01 \\
\hline \hline ArticleSequenceNumber & $:$ & 75 \\
\hline \hline ArticleCategory & $:$ & Research news \\
\hline ArticleFirstPage & $:$ & 1 \\
\hline \hline ArticleLastPage & $:$ & 3 \\
\hline \hline & & RegistrationDate : 2005-6-30 \\
\hline ArticleHistory & $:$ & OnlineDate \\
\hline ArticleCopyright & $:$ & BioMed Central Ltd2005-6-30 \\
\hline \hline ArticleGrants & $:$ & \\
\hline \hline ArticleContext & $:$ & 130596611 \\
\hline \hline
\end{tabular}




\section{Nick Atkinson}

Email: nwa@entangled.org

Detailed genetic analyses of little fire antWasmannia auropunctata colonies have revealed an unexpected mode of reproduction by males. The findings, published this week in Nature, show that males within a colony are genetically identical, implying that they are produced clonally. Effectively, male and female fire ants are two separate genetic lineages whose only sexually produced diploid progeny are sterile workers, the study authors suggest.

Denis Fournier, from Université Libre de Bruxelles in Belgium, and colleagues studied the DNA of queens, workers, males, and their sperm from 34 little ant nests in French Guiana. They expected to find a typical haplodiploidy genetic system, but instead discovered that queens possessed only maternally derived DNA, and males possessed only paternally derived DNA.

"If males are potentially in an evolutionary dead end, as is true in the little fire ant where workers are sterile and all queens are clonally produced, they do not have a means to transmit their genes to the next generation," said Fournier. Queens produce gynes (reproductively competent females) clonally, a strategy that denies males the opportunity to pass on their genes. Males are still required, however, in the production of workers, upon which a queen's own reproductive success depends even though males themselves gain nothing.

The males' response has been to evolve their own means of clonal reproduction, Fournier and colleagues say. They propose that at some stage after fertilization, maternal genetic material is lost and a haploid male offspring, encoded solely by the sperm's DNA, develops. "We could think of the males as a separate, parasitic species that uses host eggs for its own reproduction," said Fournier.

"The reality with natural history is that if you look close enough, you find remarkable patterns," commented Greg Hurst, at University College London. This well-known ant species was previously thought to have a "classic bee-ant system of genetics," in which diploid females exist alongside maternally derived haploid males. But the "fascinating bit of natural history" uncovered by Fournier and colleagues tells a more complex story, in which males and females both reproduce asexually and have thus separated into distinct genetic lineages.

"In essence, the male-female interaction in this species has become like an obligate symbiosis - the females need the males for worker production and the males need the females as a vehicle for producing eggs," said Hurst, who was not involved with the study. "But both have genetic integrity."

This unusual genetic system owes its rarity to "two improbable [evolutionary] steps," according to Rice University's David Queller, author of an accompanying News and Views piece. First, females provided the selective impetus for males to reproduce clonally by ceasing production of males. Second, males became able to parasitize queen's eggs and use them to produce clonal sons.

However, there are costs to clonality. Asexually reproducing species are vulnerable to the long-term accumulation of deleterious mutations, a process known as Muller's ratchet, Queller told The Scientist. The little fire ant could have mitigated these effects to some extent through the sexual reproduction of diploid workers, which by virtue of their increased genetic heterogenity are less susceptible to disease and parasites. 
For the hundred or so species of social insects for which the data already exist, this is the only known case in which both males and females have reverted to asexuality, Queller said. It could be "more common than we think," he said, but remains hidden because of the effort required to carry out the conclusive genetic analysis.

\section{References}

1. Global Invasive Species Database, [http://www.issg.org/database/species/ ecology.asp? $\mathrm{si}=58 \& \mathrm{fr}=1 \& \mathrm{sts}=]$

2. D. Fournier et al., "Clonal reproduction by males and females in the little fire ant," Nature, 435:1230-1234, June 30, 2005., [http://www.nature.com]

3. Denis Fournier, [http://www.unil.ch/Jahia/site/dee/cache/offonce/pid/7719]

4. S. Subramanian, "Haploid female mites," Genome Biology, 2:reports0029, August 17, 2001., [http://genomebiology.com/2001/2/9/reports/0029]

5. Greg Hurst, [http://www.ucl.ac.uk/ ucbtghu/Greg.htm]

6. David Queller, [http://dacnet.rice.edu/depts/eeb/faculty/?FDSID=930]

7. D. Queller, "Males from Mars," Nature, 435:1167-1168, June 30, 2005., [http://www.nature.com]

8. I.M. Rouzine et al., "The solitary wave of asexual evolution," PNAS, 100:587-592, January 21, 2003. 